\title{
Research on the Innovation of Construction Mode in China's "Go Global" Railway Strategy Based on Win-Win Cooperation
}

\author{
Sheng Liming ${ }^{1}$, Liu Yanhong ${ }^{1}$, Liu Yuming ${ }^{2}$, Chen Yun ${ }^{1}$ \\ 1. Engineering Management Center, China Railway, Beijing 100844, China \\ 2. School of Economics and Management, Beijing Jiaotong University, Beijing 100044, China
}

\begin{abstract}
This paper expounds upon the current situation of China's "Go Global" railway construction modes, the major challenges, and the new development trends in the large international engineering contracting market. Utilizing the Jakarta-Bandung high-speed rail project in Indonesia as an example, the innovation practices of the construction mode in China's "Go Global" railway strategy is explored in depth, and three development paths are presented: development toward a whole railway industry value chain from the integration of railway investment, construction, and operation; a comprehensive development model of implementation for the "railway+supporting industry;" and a development model of public-private partnership (PPP) cooperation. Finally, this paper proposes safeguard measures based on four aspects, namely establishment of a public service platform in China's "Go Global” railway strategy, enhancing the local development level, reinforcing the building of a talent team, and cultivating the concordance and integration capabilities for the whole railway industry value chain resource.
\end{abstract}

Keywords: win-win cooperation; China's railway; “Go Global” strategy; construction mode; innovation

\section{Introduction}

The constructions under China's Belt and Road Initiative are proceeding at a steady rate. As the leading industry and key area of international cooperation in the "Go Global" strategy, China's railway awaits unprecedented opportunities. Faced with profound changes in the international infrastructure construction market, some construction modes, which consider the integration of investment, construction, and operation, as well as comprehensive development as the core objectives, are emerging around the world. To innovate, business models based on the "win-win cooperation, risk sharing" concept in large infrastructure construction have generally been recognized and accepted by developing countries. Against this backdrop, it is of great theoretical and practical significance to study the innovation in the construction mode of China's railway "Go Global."

\section{Current situation and main challenges of China's "Go Global" railway construction mode}

\author{
2.1 Connotation of China's "Go Global” railway \\ construction mode
}

China's "Go Global" railway construction mode refers to the project construction and management mode, which is determined by the host country's socioeconomic development, overseas railway construction project characteristics, owner characteristics, investment and financing conditions, external environmental

Received date: August 22, 2017; revised date: September 14, 2017

Corresponding author: Chen Yun, China Railway, Engineer. Major research fields include railway science and technology management and engineering construction informatization. E-mail: ch.yun@163.com

Funding program: CAE Advisory Project “Research on China's 'Go Global' Railway Strategy” (2015-ZD-11)

Chinese version: Strategic Study of CAE 2017, 19 (5): 038-043

Cited item: Sheng Liming et al. Research on the Innovation of Construction Mode in China's "Go Global” Railway Strategy Based on Win-Win Cooperation. Strategic Study of CAE, https://doi.org/10.15302/J-SSCAE-2017.05.007 
factors, Chinese national strategic demands and policy support, and other factors. The construction mode, in a broad sense, can be extended to the pre-project planning consultation and then to the post-operation management phases, thus covering the whole life cycle of railway projects. China's "Go Global" railway construction mode involves the overseas railway project investment and financing mode, project governance structure, project contracting model, project operation management mode, product service components and standards, project revenue and risk sharing mode, and other core elements [1]. Therefore, China's "Go Global" railway construction mode is essentially a business model of overseas railway projects, and its mode selection and innovation are influenced by the host country's national conditions, project characteristics, China's expectations and goals, external competition, and many other factors. China's "Go Global" railway construction mode should be provided with sufficient support to improve its adaptability and flexibility.

\subsection{Current situation of China's "Go Global" railway construction mode}

Among the several types of China's railway "Go Global construction modes, Finance and Engineering-Procurement-Construction $(\mathrm{F}+\mathrm{EPC})$ construction mode is the main one.

\subsubsection{F+EPC construction mode}

The $\mathrm{F}+\mathrm{EPC}$ is the general contracting mode of "financing+EPC." This mode integrates the project financing and contracting links by: determining the project construction capital sources; emphasizing the role of the design core; optimizing the whole project; arranging the cross-referencing and coordination of the design, procurement, and construction stages in a reasonable manner; and then taking full advantage of large construction enterprises in financing, project management, comprehensive integration, and technological innovation, to effectively and efficiently achieve the project construction goals [2]. Kenya's first standard gauge railway from the port of Mombasa to the country's capital Nairobi, which officially opened in May 2017, was built using the F+EPC mode. The construction involved a total investment of USD 3.8 billion, which was raised by the Government of Kenya using the mixed loan model, that is, $90 \%$ of the funds are provided by the Export-Import Bank of China and $10 \%$ by the Kenyan government. This railway was implemented by the Chinese enterprises under the EPC mode, including the whole process of railway project construction, such as a feasibility study at the early stage of the project, preliminary design, construction design, implementation of works under track, line laying, station building construction, procurement and installation of "Four-Electrical-Engineering" (communication engineering, signal engineering, power engineering, and electrification engineering) above the track level, vehicle supply, and integrated commissioning.

\subsection{2 $\mathrm{EPC}+\mathrm{O} \& \mathrm{M}$ construction mode}

$\mathrm{EPC}+\mathrm{O \& M}$ (operation \& maintenance), based on the general contracting mode of the EPC project, integrates project construction links with the operation and maintenance after the project completion, and emphasizes the resources' integration and coordination role of the project general contractor in the following stages: project design, procurement, construction, and operation and maintenance. For example, the Makkah Metro Pink Line (Al Mashaaer Al Mugaddassah Metro Southern Line, i.e., Mecca Light Rail) in Saudi Arabia was constructed, operated, and serviced under the EPC $+\mathrm{O} \& \mathrm{M}$ mode. The Chinese railway enterprise signed a contract with the Ministry of $\mathrm{Mu}$ nicipal and Rural Affairs (MMRA) of Saudi Arabia to construct the Mecca Light Rail, which was under the infrastructure cooperation agreement of the two governments; they agreed to build and operate the light rail using the $\mathrm{EPC}+\mathrm{O} \& \mathrm{M}$ mode. A certain Chinese railway enterprise, signed an operation subcontract that makes it, as the operator, responsible for the operation and maintenance of the Mecca Light Rail.

\subsubsection{F+EPC+O\&M construction mode}

The construction and operation management mode, which includes project financing, general contracting, and operation management and maintenance, can be derived on the basis of the $\mathrm{F}+\mathrm{EPC}$ construction mode by extending the service content of the operation phase; thus, we get the $\mathrm{F}+\mathrm{EPC}+\mathrm{O} \& \mathrm{M}$ construction mode. The Addis Ababa (capital of Ethiopia)-Djibouti railway project is an example of a project under this mode. This railway, constructed based on the standard construction of the China electrified railway and jointly constructed by several Chinese railway enterprises, is the first modern electrified railway in Africa. The total project investment was about USD 4 billion, of which USD 2.9 billion were obtained as commercial loans (provided by the Chinese banks at the interest rate it charges for commercial loans) that accounted for $70 \%$ of the railway's Ethiopian section and for $85 \%$ of the section in Djibouti. This railway's operation management will be " $6+2$," that is, six years of operation and maintenance plus two years of technical services, and eventually, Ethiopia and Djibouti will take over the railway.

\subsection{Main challenges of China's “Go Global” railway construction mode}

2.3.1 There is a serious shortage of funds for infrastructure construction in the host country

The key areas of China's "Go Global" railway construction mode are Southeast Asia, South Asia, Central Asia, and Africa, among others. Many countries in these regions have a powerful intrinsic motivation to develop their national economy through infrastructure construction, including railways, but at the same time, they have a serious shortage of funds for such infrastructure construction. Therefore, they hope that Chinese companies 
can finance their infrastructure construction projects, especially the railways. The Addis Ababa-Djibouti railway project and Mombasa-Nairobi railway project are good examples of the use of the "Go Global" construction mode. However, China's "Go Global" railway construction mode relies heavily on the financial support based on the foreign policy of the Chinese government; in the capital market, particularly the international capital market, some related enterprises lack the ability and experience for commercial financing [3].

2.3.2 There is a serious shortage of railway construction and management talents in the host country

The railway is a complex technical system of large infrastructure projects, from the planning and construction to operation and maintenance, involves all kinds of professional skills and management systems, and needs all aspects of technology and management talents. There is generally a serious shortage of railway construction and management talents in the countries in which China's "Go Global" railway construction mode is utilized. Especially, the shortage of railway operation and maintenance talents has negatively affected the efficiency of the built railways. Therefore, in railway project cooperation, host countries' primary demand is assistance for investment in the railway construction, for participation in railway operation and maintenance management, and for sharing risks and interests.

2.3.3 Chinese railway enterprises lack of the international talent team needed for the "Go Global" strategy

Research has shown that the key obstacle in the implementation of China's "Go Global" railway strategy is the lack of a team with international talent. China's "Go Global" railway strategy urgently needs international technology and interdisciplinary management talents who have good foreign language, technical, and management skills and familiarity with international market practices. Thus, the lack of international talent team will be the biggest challenge for the Chinese railway enterprises" "Go Global" strategy [4].

2.3.4 The concordance and integration capabilities of the whole railway industry value chain resources of Chinese railway enterprises are still in their infancy

The whole railway industry value chain consists of railway network planning, problem research, project planning, design consultation, comprehensive development, investment and financing, project construction, equipment manufacturing, operation management, and other core elements. Railway construction, equipment, and operation are representative elements of China's "Go Global" railway strategy. Compared with the international railways, Chinese railway backbone enterprises' strong advantages over top international engineering contracting enterprises are in engineering construction, and manufacturing of equipment and other industrial chain parts; however, their clear weaknesses are in investment and development, overseas financing, and operation management, as well as the lack of concordance and integration capabilities for the whole railway industry's value chain resource in large-scale railway construction projects [5].

\section{Thoughts on the innovation practices of China's "Go Global" railway construction mode}

\subsection{New development trends in construction modes in large international infrastructure projects}

In recent years, in the face of profound changes in the international political and economic situations and the international project contracting market, the large international infrastructure project construction mode shows a new development trend, mainly as follows.

\subsubsection{Integration of investment, construction, and operation}

There has been a shortage of infrastructure and construction funds in many developing countries, and there has been a lack of operation management and technology talents after infrastructure completion [6]. Owing to these situations, host country governments hope that foreign contractors would participate in the investment, construction, and management of large-scale infrastructure projects by adopting the mode of integrated investment, construction, and operation.

\subsubsection{Comprehensive supporting development}

Amid the global economic integration, large-scale international engineering construction projects are increasingly adopting the trend involving the use of a comprehensive supporting development model. On the one hand, carrying out comprehensive supporting development for large-scale international infrastructure is conducive to maximizing socioeconomic benefits, and greatly expanding the profit space and channels; on the other hand, international engineering contractors' resource allocation and ability exerting will also be in demand owing to the stricter requirements and higher standards.

\subsubsection{Bank enterprise cooperation}

The international engineering projects undertaken by Chinese enterprises mainly rely on buyer's credit and preferential government loans, and adopt the F+EPC contracting mode; in contrast, build-operate-transfer (BOT), public-private partnership (PPP), and other construction financing modes are not so widely used in overseas markets [7]. The development trend in the international project contracting market shows that strong and stable financing capacity is becoming the key factor for international engineering contractors to win large projects. Therefore, large construction contractors and financial institutions, such as banks, should establish strategic partnerships, realize the organic integration and 
complimentary resources of financial and physical capital, and shape the comprehensive competitiveness; all these factors will become the powerful core elements a contractor needs to compete in the large international engineering market [6].

\subsubsection{Localization cooperation}

Competition in the international project contracting market has intensified of late; in the process of project construction, many host countries have begun to demand that international contractors make full use of the countries' natural and social resources, support the development of related industries [6], and bring such countries greater economic and social benefits through local cooperation. For example, during the construction of the Addis Ababa-Djibouti railway project, more than 15000 local staff members were trained and employed, and the localization rate of project personnel during the peak construction period was over $90 \%$. Therefore, the development trend of localization of cooperation generally becomes a model of international project contracting cooperation for host countries and international contractors to achieve a win-win situation [6].

\subsection{Exploration of the innovation practices of China's "Go Global" railway construction mode}

Since China proposed the Belt and Road Initiative, China's railway has actively carried out construction mode innovation practices in the process of implementing the "Go Global" strategy. The Jakarta-Bandung high-speed rail (HSR) project in Indonesia is a good example for analysis. The HSR line, which spans almost $150 \mathrm{~km}$ and runs from the Indonesian capital of Jakarta to its fourth largest city, Bandung, has the highest design speed of more than $300 \mathrm{~km} / \mathrm{hr}$ and required an investment of about USD 5.135 billion. This project adopts the cooperative model of construction and operation management with joint financing from the Chinese and Indonesian sides, and presents an example of exploration and innovation of the international railway construction and management mode, that is, a business-to-business approach. The project is led by the governments of the two countries and establishes the cooperation among the enterprises and financial institutions of the two countries. Kereta Cepat Indonesia China, established by the bilateral enterprises with joint funds, is responsible for the investment, construction, and operation management. The Indonesian consortium contributed $60 \%$ of capital for the HSR project, whiles Chinese railway enterprises contributed the remaining $40 \%$; the project's capital accounts for $25 \%$ of the total investment capital; the remaining $75 \%$ is from the loans provided by the Chinese banks. The Jakarta-Bandung HSR adopted the EPC general contracting mode. It will be the first key project of China's high-speed railway "Go Global" that is all-encompassing, that is, from the technical standards, survey and design, project construction, equipment manufacturing, and material supply to the operation management, talent training, and comprehensive development along the railway line. The Chinese enterprises have applied the comprehensive supporting development business model to the Jakarta-Bandung HSR project, including the project construction and urbanization, commercialization, and industrialization of railways stations, with nodes along the route that could be organically combined. The project aims to take full advantage of the regional radiation effects of HSR on the routes and stations to achieve the optimal overall benefits and to promote a development upgrade of the traditional railway construction modes [6]. Some thoughts on the innovation practices of China's "Go Global" railway construction mode are as follows.

3.2.1 Inevitable choice of the Chinese railway industry's "Go Global" transformation and upgrade

In the past, China's "Go Global" railway strategy was at the bottom of the industry value chain, obtaining railway construction projects that mainly rely on the foreign preferential loans by the Chinese government, and implementing the construction as a project contractor. In the Jakarta-Bandung HSR project, Chinese enterprises will undertake tasks during different stages of the total project lifecycle, from investment and financing, planning and design, construction, and equipment manufacturing to the operation management and talent training after project completion. Chinese enterprises will play "four important roles": investors, builders, contractors, and operators. The project adopts the cooperative mode of investment, construction, and operation integration, or more specifically, a completely new cooperative mode comprising three elements, that is, the integration of investment, construction, and operations, comprehensive development, and localization of cooperation.

This kind of transformation will mirror the change from the low-end aspect of railway project construction to the high-end value chain, including investment, as well as financing, planning, and design, operation management, and comprehensive development. For the Chinese railway enterprises, this cooperative mode is the inevitable choice for both the transformation and upgrade, and even for development improvement. Undoubtedly, the innovation of a construction mode can bring opportunities but can also produce risks. Enterprises should understand the market tendencies and reasonably avoid risks.

3.2.2 Reflects the win-win cooperation concept of the Belt and Road Initiative

As a major transportation infrastructure construction project of the Belt and Road Initiative, the Jakarta-Bandung HSR project is of great significance to Indonesia's socioeconomic development. It is a result that links the Chinese 21st Century Maritime Silk Road and Indonesia's Global Maritime Fulcrum. This project will deepen the railway cooperation between China 
and Southeast Asian countries, and accelerate the transportation infrastructure interconnection and intercommunication between China and the countries along the Belt and Road Initiative. The bilateral cooperative mode and content is the concrete application of the principle of "co-consult, co-construct, and co-share." The project fully reflects the Chinese government's consideration of the host country's actual situation and interests. The Chinese side had showed respect toward Indonesia and had not required any financing or guarantee from its government. The construction mode innovation practices in this project reflects the concept of the Belt and Road Initiative, that is, mutually beneficial, pragmatic, and win-win cooperation. It also embodies the Chinese and Indonesian governments' common pursuit of creating benefit, fate, and responsibility communities.

\section{Innovation and development paths of China's "Go Global" railway construction mode}

\subsection{Basic principles in the innovation of China's "Go Global" railway construction mode}

The following basic principles should be followed in the innovation of China's "Go Global” railway construction mode.

4.1.1 Adhere to the principle of "co-consult, co-construct and co-share"

As the main construction component of facilities connectivity in the Belt and Road initiative, the overseas railway construction project is an important symbol of the success of the Belt and Road initiative construction. Therefore, in the process of China's "Go Global" railway construction mode, the joint responsibility by China and the host country must always be emphasized in the negotiation of major railway matters, participation in the railway project construction, and sharing of the benefits and risks of the railway project operation. This principle simply lets the concept of win-win cooperation fall to the ground, take root and germinate, and then bear rich fruit.

4.1.2 Adhere to the principle of "market-oriented, corporate operation"

China's "Go Global" railway construction mode aims to pursue railway construction projects in different countries and with different attributes; regardless of whether they are Commonwealth projects or commercial projects, the Chinese and host country enterprises must adopt the "Go Global" construction mode to conduct project management in accordance to international market practices throughout the whole project lifecycle [1].

4.1.3 Adhere to the principle of "adaptation to local conditions and made-to-measure"

China's "Go Global" railway construction mode will pursue different target markets, countries with different development levels and demands, and railway projects with different characteristics; therefore, it should adhere to the principle of "adaptation to local conditions and be made-to-measure." The construction mode of each overseas railway project should be developed to meet the host country's demands and socioeconomic development [1].

\subsection{Development paths of the innovation of China's "Go Global" railway construction mode}

Based on the foregoing analysis, the development paths of the innovation of China's "Go Global" railway construction mode can be explored based on the following aspects.

4.2.1 Development toward a whole railway industry value chain from the integration of railway investment, construction, and operation

Although host countries face serious shortages of funds and management personnel for infrastructure construction, they hope that Chinese enterprises can participate in the railway construction and management of the whole project lifecycle. Against this backdrop, the investment, construction, and operation integration construction mode of the whole industry chain for overseas railway projects should be selected. At present, F+EPC is the main construction mode for China's "Go Global" railway strategy. This construction mode is at the low to medium end of the whole industry value chain, in which there is limited space for creating value and there is low return on investment. It is recommended that China's railway refer to successful overseas railway construction projects as examples, to integrate the industry chains' superior resources, and to actively explore the upstream business development, including that in project investment and financing, design and consulting, operation and maintenance. Then China's railway can be expected to realize a comprehensive integration of the whole railway project industrial chain, to adopt the construction mode of investment, construction, and operation integration, and to achieve incremental value increases and a sustainability mechanism for railway investment returns.

4.2.2 Comprehensive development model of implementation for "railway+supporting industry"

The railway, as the main traffic artery, must adopt a comprehensive development model that is tailored to the related facilities along the railway lines, to achieve the optimal level of socioeconomic benefits. For example, a project should carry out a comprehensive development of the railway and its corresponding stations, new commercial city, port, logistics park, and industrial park. The Jakarta-Bandung HSR possesses unique geographical advantages and obvious economic impacts; its con- 
struction will lead to the development of supporting industries, including smelting, manufacturing, infrastructure construction, electricity, electronics, services, and logistics in the areas served by the railway line. As the project is expected to form the Jakarta-Bandung economic corridor, the comprehensive development mode of the "railway + supporting industries" should be actively explored. On the one hand, the comprehensive development model can help maximize the railway project's benefits and take full advantage of the value-added space of the railway's value chain; on the other hand, it can help maximize the project's enormous surplus value, and thus, expand the scope of the railway's value chain and increase the revenue source channel of the railway investment.

\subsubsection{Development model of PPP cooperation}

As a large infrastructure project, the railway is essentially considered a commonweal investment project. By applying the PPP cooperation development mode in railway construction, the market mechanism can be influenced in terms of the railway infrastructure construction investment and financing, and construction and operation management; thus, this development mode has many advantages, such as attracting investors for the railway construction, reducing the host country government's financial burden, improving efficiency, and reducing project cost. Therefore, in large-scale and qualified overseas railway projects, it is recommended that the Chinese and host country governments first establish the PPP cooperation mode framework, and then register a joint-stock company with the project company as its carrier. Further, sign the franchise agreement with the host government, and include in the components railway project investment and financing, construction and operation management, and formation of "complementary advantages, wholecourse cooperation, benefit-sharing, risk-sharing" interests and community relations. Both countries should actively explore the PPP cooperation development mode to realize the organic integration and incremental value of the railway project's whole life cycle value chain, and ultimately, to promote a win-win situation among all parties.

\section{Safeguard measures of the innovation of China's "Go Global" railway construction mode}

Against the backdrop of China's Belt and Road Initiative, China's "Go Global" railway construction mode faces opportunities and has a long way to go. Chinese railway enterprises should combine the Chinese railway industry's advantages with foreign development demands, pay attention to the host country's interests and concerns, and consult at length with the participating enterprises, to determine the mutually beneficial cooperation construction mode and achieving a win-win situation with China's "Go Global" railway enterprises and the host country's socioeconomic development. The exploration of the innovation of China's "Go Global" railway construction mode could be discussed and implemented by focusing on the following aspects.

\subsection{Establishment of a public service platform in China's "Go Global" railway strategy}

Overseas construction projects are difficult and risky. For the "Go Global" strategy to succeed, it is very necessary to do market research and obtain market intelligence. However, a single enterprise has a limited channel and ability to obtain information resources, making it difficult for them to fully grasp the political and economic environments in different countries, and consequently, may prompt the enterprise to make blind investments or incur risks. Therefore, information resources from governments, industry associations, commerce chambers, businesses, financial institutions, and intermediary services should be fully integrated to establish and gradually improve China's "Go Global" railway public service platform, to accelerate information acquisition and exchange between different enterprises from the industrial chain, to improve the information sharing system, and to strengthen coordination and business docking between enterprises. A cooperative organization mode should be established among "Go Global" enterprises. Relying on the platform, key overseas project research should be conducted on "Go Global" enterprises, provide them with consulting services, including in policy, law, market access, and technology, which are based on the information service reprocessing. Further, industry associations, commerce chambers, and intermediary agencies should be cultivated and guided to give full play to the functions that could not be provided by the relevant government departments. These organizations offer services for "Go Global" enterprises and play the role of a bridge and link.

\subsection{Enhancing the local development level}

Local development is the only road for the innovation and sustainable development of China's "Go Global" railway construction mode and is an important measure to realize a win-win cooperation between China and the host country. Enterprises involved in China's "Go Global" railway strategy should enhance the local development level in terms of the following aspects raw material localization, equipment manufacturing localization, technical standards localization, research development localization, human resources localization, enterprise culture localization, and operation management localization [6]. "Go Global" enterprises should cultivate and support the local railway industries, strive for the host country's support, improve China's international image, provide a good external public opinion environment for market exploitation, and contribute to the host country's socioeconomic development, while realizing the enterprises' own sustainable development. 


\subsection{Reinforcing the building of a talent team}

The international talent team is the key aspect of the innovation in China's "Go Global" railway construction mode. To reinforce the building of such a talent team [8], five aspects are required: first, to select excellent talents through competition within enterprises, including excellent employees with training potential in the host country; second, to recruit excellent talents through other enterprises; third, to cultivate professional talents who are proficient in international management, finance, and law, by establishing a railway academic major in China's cooperative universities, or through dual-track training in both enterprises and universities; fourth, to engage high-level overseas talents through international recruitment; and finally, to select Chinese students in China's "Go Global" railway host countries and effectively absorb international talents found suitable.

\subsection{Cultivating the concordance and integration capabilities for the whole railway industry value chain resource}

The China's railway industry should continuously cultivate and improve the concordance and integration capabilities for the whole railway industry value chain resource and enhance its core competitiveness in the international market. The integration ability of the whole industry's value chain resources is the imminent driving force to improve the whole industry value chain's integration capability and business mode innovation. China's large railway backbone enterprises should strengthen the integration capability of the whole industry value chain by the following measures: business content optimization through internal resources, external resources mergers and acquisition, strategic restructuring, strategic alliances, and cooperative partnerships with interested parties, bank-enterprise cooperation, local cooperation, and others. Furthermore, China's large railway backbone enterprises should cure the whole industry value chain businesses' weakness in the areas of comprehensive development, project investment financing, asset operation management, and others. They should focus on cultivating the whole industry chain's integration ability in large-scale railway construction projects.

\section{References}

[1] Chen Y. Mode selection of railway project "Go Global" [J]. International Project Contracting \& Labour Service, 2017(1): 61-62. Chinese.

[2] Wang M J, Cui Z D, Song C P. Strategic concept of large construction enterprise general operations F-EPC projects [J]. Journal of Civil Engineering and Management, 2013, 30(1): 56-61. Chinese.

[3] Ye K H, Huang Y, Zhao R X. Research on obstructing of "Go Globe" for Chines EPC [J]. Construction Economy, 2014, 35(12): 9-12. Chinese.

[4] Xu F. Ten challenges for the "Go Global" of China's high-speed rail and strategic solutions [J]. Frontiers, 2016(7): 58-78. Chinese.

[5] Liu Y H, Liu Y M. Research on the experience and lessons of Chines railway industry "Going Out" [J]. Construction Economy, 2015, 36(12): 20-23. Chinese.

[6] Xiao J, Liu Y M. Research on current and development trends of overseas project contracting business of China state-owned enterprise [J]. Construction Economy, 2016, 37(8): 15-19. Chinese.

[7] Fang Y M. Strategic research on the "Going Out" of Chinese railway industry [M]. Hefei: Anhui University Press, 2010. Chinese.

[8] Chen Y. Discussion on establishment of human resource management system of overseas railway project [J]. Railway Transport and Economy, 2016, 38(8): 71-75. Chinese. 